\title{
Trihexyphenidyl Triggered Hypomania in a Bipolar Patient
}

\author{
Eren Yıldızhan ${ }^{1}$, Serap Batmaz ${ }^{2}$, Nazan Karagöz Sakallı${ }^{1}$ Erhan Kurt ${ }^{1}$
}

\section{ÖZET:}

iki uçlu bozukluklu bir hastada triheksifenidil ile tetiklenen hipomani

Düzenli düșük doz klorpromazin kullanımı sonrasında gelișen bir tardiv diskinezi olgusu bildirmekteyiz. Olgudaki tardiv diskinezinin tedavisinde antikolinerjik bir ajan olan triheksifenidil (THX) kullanıldı. Tedavi yanıtı iyi olmakla beraber, THX kullanımı sonrasında kısa süreli hipomanik dönemler görüldü. Hastanın uzun süredir düzenli tedavi altında ve belirtisiz oldug̃u dikkate alındıg̃ında, tedaviye eklenen THX'in hastalık seyrini olumsuz etkiledig̃inden ya da hipomaniyi tetiklemiș olabileceg̃inden șüphelendik. Söz konusu hipomanik dönemler kısa süreli idi ve olanzapin kullanımı ile kontrol altına alındı. THX dozunu artırdı̃̆ımızda ise hastanın mizacında yükselme oldug̃unu saptadık. Ailesinde iki uçlu bozukluk öyküsü olması ve iki uçlu bozuklug̃un erken başlangıçı tipine sahip olması olgumuzda tardiv hareket bozuklug̃unun görülmesi olasilıg̃ını artırmış olan dig̃er etkenlerdi. THX tardiv diskinezi tedavisinde etkili bir seçenek olarak kabul edilmekle birlikte, bu ajanın iki uçlu olan hastalarda hastalık seyrinde deg̃ișiklig̃e yol açma olasılıg̃ı incelemeye deg̃erdir.

Anahtar sözcükler: triheksifenidil, hipomani, tardiv diskinezi

\section{ABSTRACT:}

Trihexyphenidyl triggered hypomania in a bipolar patient

We observed a case of tardive dyskinesia after regular use of low dose chlorpromazine. An anticholinergic agent; trihexyphenidyl (THX) was prescribed to treat the tardive dyskinesia. The treatment response was satisfactory, but brief hypomanic episodes occurred. Because the patient was symptom free for long periods of time, we suspected that THX might have had a negative effect on the course of the disease or it might have induced hypomania. The hypomanic episodes were controlled with short term use of olanzapine. When the dose of THX was further increased, elevation of mood occurred. The history of bipolar disorder in his family and having the early onset type of bipolar disorder were features of our case that made the tardive movement disorder more likely. Although THX may be an effective option in tardive dyskinesia, possible impact on the course of the disorder in bipolar patients should be considered.

Key words: trihexyphenidyl, hypomania, tardive dyskinesia

Journal of Mood Disorders 2012;2(2):77-9
${ }^{1} \mathrm{MD}$, Bakırköy Research and Training Hospita For Psychiatry, Neurology and Neurosurgery, Department of Psychiatry, istanbul-Turkey ${ }^{2} \mathrm{MD}$, Istanbul Universty, Medical Faculty of Istanbul, Department of Psychiatry, istanbul-Turkey;

Yazıșma Adresi / Address reprint requests to: Eren Yildizhan, Prof. Dr. Mazhar Osman Bakırköy Ruh Sag̃lıg̃ı ve Sinir Hastalıkları Eḡitim ve Araștırma Hastanesi,

istanbul-Türkiye

Telefon / Phone: +90-212-543-6565

Elektronik posta adresi / E-mail address: erenyildizhan@hotmail.com

Kabul tarihi / Date of acceptance: 06 Nisan 2012 / April 06, 2012

Bag̃ıntı beyanı

E.Y., S.B., N.K.S., E.K.: Yazarlar bu makale ile ilgili olarak herhangi bir çıkar çatıșması bildirmemișlerdir.

Declaration of interest: E.Y., S.B., N.K.S., E.K.: The authors reported no conflict of interest related to this article.

\section{INTRODUCTION}

Anticholinergic agents are frequently used in the treatment of drug induced acute extrapyramidal side effects but effectiveness of these agents in tardive movement disorders is enigmatic. On the contrary, it has been suggested that antipsychotic agents may be even worsening tardive dyskinesia

We report a case of bipolar man with tardive dyskinesia. Brief episodes of hypomania were induced by trihexyphenidyl (THX) which had been used to treat the tardive dyskinesia.

\section{CASE REPORT}

MR A.T. was a 41 years old Caucasian man with 26 years history of bipolar disorder. He had history of bipolar disorder in three of his brothers.

His first hospitalization was when he was 15 years old. He was treated with haloperidole which was substituted with chlorpromazine after a few days because of acute dystonia due to haloperidole. He was given lithium or chlorpromazine and lithium combination as maintenance treatment. For seven years (from 1994 to 2001) he was symptom free with monotherapy of lithium $1200 \mathrm{mg} /$ day. 
After this period, he admitted to the clinic with a hypomanic episode. He was given chlorpromazine 400mg/ day and biperiden $4 \mathrm{mg}$ /day as an adjunct to lithium monotherapy and chlorpromazine was decreased to 50 $\mathrm{mg} /$ day because of parkinsonism which subsided after dose reduction. His new maintenance treatment was chlorpromazine $50 \mathrm{mg} /$ day and lithium $1200 \mathrm{mg} /$ day and this was followed by another seven years of symptom free period.

After seven years of continuous chlorpromazine (50mg/day) and lithium therapy, the patient admitted to the clinic with dystonic movements of face, head, neck and arms. He was diagnosed tardive dyskinesia according to the DSM IV and Abnormal Involuntary Movements Scale (AIMS) score was 18. Chlorpromazine was discontinued and quetiapine with varying doses $(400 \mathrm{mg} /$ day, $600 \mathrm{mg} /$ day and $200 \mathrm{mg}$ /day) was prescribed but no improvement was observed. He was given clozapine $12,5 \mathrm{mg} /$ day but he could not tolerate because of intense restlessness and dysphoria. Valproic acid $1000 \mathrm{mg} /$ day and propranolole 60 $\mathrm{mg} /$ day was prescribed and that was not also effective.

Modest improvement in tardive dyskinesia was observed after addition of the anticholinergic agent which is trihexyphenidyl $2 \mathrm{mg} /$ day. After that, his AIMS score was 12 .

His treatment regimen at that time was lithium $1200 \mathrm{mg} /$ day, valproic acid 1000mg/day, THX $2 \mathrm{mg} /$ day. After partial improvement of dyskinetic movements, an episode of hypomania occurred; he was euphoric with excessive energy so that he was sometimes singing in public buses, he was sleeping less than normal and his amount of talking was increased that could easily be seen during the interview.

This episode of hypomania subsided with addition of olanzapine $5 \mathrm{mg}$ / day for 10 days. In this index visit, the blood levels of mood stabilizers were in the therapeutic range (serum levels; lithium: $0.78 \mathrm{mmol} / \mathrm{L}$, valproat: 86.12 $\mu \mathrm{g} / \mathrm{ml})$.

Afterwards, reserpine $0,50 \mathrm{mg} /$ day and chlortalidone $100 \mathrm{mg} /$ day was prescribed but modest improvement was observed. 6 months later another hypomanic episode that is similar in severity to the previous one occurred. Young mania rating score was 12 (serum levels; lithium: 0.51 $\mathrm{mmol} / \mathrm{L}$, valproat: $74.37 \mu \mathrm{g} / \mathrm{ml}$ ). This episode was controlled with olanzapine $5 \mathrm{mg}$ /day for 5 days and that is followed by a subsyndromal depressive episode. When
THX was titrated up to $4 \mathrm{mg}$ /day, a further improvement in dystonic movements was observed with spontaneous relief from the depressive symptoms, his AIMS score was 8 .

His current medication is now lithium $900 \mathrm{mg} /$ day, valproic acid $1000 \mathrm{mg} /$ day, THX $4 \mathrm{mg} /$ day, reserpine/ chlortalidone $0.50 / 100 \mathrm{mg} /$ day, clonazepam $2 \mathrm{mg}$ /day. If he forgets taking his medication, the dystonic movements worsen and when he takes his medication they improve again.

\section{DISCUSSION}

The patient has history of acute dystonia with haloperidole and this is relieved by substituting that agent with chlorpromazine. Tardive movements that occurred later may be speculated to be a side effect of haloperidole, but it should be noted that he hadn't been prescribed haloperidole since 1994 and tardive dyskinesia first occurred in 2008, following 7 years of symptom free treatment with chlorpromazine and lithium.

In 2001, a brief period of parkinsonism was observed after titration of chlorpromazine to $400 \mathrm{mg}$ /day because of hypomania, and this parkinsonian symptoms were relieved by dose reduction to $50 \mathrm{mg} /$ day. That might have been a sign of increasing dopamine hypersensitivity in the patient. At that moment, when the parkinsonism had been observed, discontinuing chlorpromazine might have been more appropriate instead of dose reduction, but the evidences favoring this decision is still inadequate.

The role of lithium in this case is difficult to interpret because of the confounding results in the literature, there are evidences that lithium has potential to decrease the risk of tardive dyskinesia, but long term lithium treatment is also associated with increased tardive dyskinesia risk $(3,4)$. In our case, there is continuous lithium treatment without cessation.

Hayashi et al. (5) reported a case of tardive dystonia which is effectively treated with THX. Euphoric effects of anticholinergic agents has been known from the literature (6) but although we found reports of psychosis induced by anticholinergic agents (7), we didn't find any cases of hypomaniainduced byTHX. Despite he was on continuous lithium and valproate protection, THX induced hypomania. In 1983, Tollefson and Senogles (8) suggested a cholinergic role in the mechanism of lithium in mania. The addition of THX might have a role of diminishing the 
effectiveness of lithium prophylaxis. Disappearance of the subsyndromal depression after titrating.

THX up to $4 \mathrm{mg}$ also suggest that THX may have an effect of elevating the mood. Koszewska and Rybanowski (9) reported in their retrospective study that mood conversions from depression to mania occurs more frequently in tricyclic antidepressants than non tricyclic antidepressants and added that it might be the anticholinergic activity that causes the higher frequency of

\section{References:}

1. Kane JM, Jeste DV, Barnes TRE et al. Tardive dyskinesia: a task force report of the American Psychiatric Association. Washington: American Psychiatric Press 1992.

2. Waddington JL, Youssef HA. Tardive dyskinesia in bipolar affective disorder: aging, cognitive dysfunction, course of illness, and exposure to neuroleptics and lithium. Am J Psychiatry 1988;145:613-616.

3. Kane JM, Jeste DV, Barnes TRE. Tardive dyskinesia in affective disorders. Journal of Clinical Psychiatry 1999;60:43-47.

4. Pert A, Rosenblatt JE, Sivit C, Pert CB, Bunney WeJr. Long-term treatment with lithium prevents the development of dopamine receptor supersensitivity. Science 1979;135:509-514.

5. Hayashi Y, Ohyagi Y, Inoue I et al. A case of amoxapine induced tardive dystonia successfully treated with a low dose anticholinergic agent. Rinsho Shinkeigaku 2000;40:367-371. mood conversion during tricyclic antidepressant therapy. THX could have induced the hypomania with such a mechanism in our case. For Mr.A.T., strongly positive family history of bipolar disorder and early onset of the disorder are other risk factors for manic switch (10).

THX is a treatment option in tardive dyskinesia although induction of hypomania in bipolar patients is a possibility. Rather than discontinuing THX, addition of antipsychotic treatment can be effective.

6. Fleischhacker WW, Barnas C, Günther V, Meise U, Stuppack C, Unterweger B Mood-altering effects of biperiden in healthy volunteers. J Affect Disord 1987;12:153-157.

7. Clarke LA, Cassidy CW, Catalano MC Psychosis induced by smoking cessation clinic administered anticholinergic overload. Annals of Clinical Psychiatry, 2004;16:171-175.

8. Tollefson GD, Senogles S A cholinergic role in the mechanism of lithium in mania. Biol Psychiatry 1983;18:467-479.

9. Koszewska I, Rybakowski JK Antidepressant-induced mood conversions in bipolar disorder: a retrospective study of tricyclic antidepressant drugs. Neuropsychobiology 2009;59:12-6.

10. Othmer E, Desouza CM, Penick EC et al. Indicators of mania in depressed outpatients: a retrospective analysis of data from the Kansas 1500 study. J Clin Psychiatry 2007;68:47-51. 